\title{
ANGGOTA REDAKSI
}

PELINDUNG

Dekan Fakultas Ekonomi

Universitas Mercu Buana Yogyakarta

(Drs. Raswan Udjang, M.Si)

\section{PEMIMPIN REDAKSI}

M.I. Andriani Novitasari, SE, M.Si

\section{SEKRETARIS REDAKSI}

Rochmad Bayu Utomo, SE, M.Si, Ak, CA

Zaenal Wafa, M. Kom

\section{DEWAN REDAKSI}

Dr. Greg Shailer, BCom., MCom., FCPA. (The Australian National University Canbera)

Dr. Harun Harun, M.Acc, CA (University of Canberra)

Prof. Dr. Indra Bastian, MBA, CMA., Akt (Universitas Gadjah Mada Yogyakarta)

Dr. Sri Suryaningsum, MS.i, Ak, CA (Universitas Pembangunan Nasional Veteran)

Wisnu Haryo Pramudya, SE, M.Si, Ak, CA (Akademi Akuntansi YKPN)

Tutut Dewi Astuti, SE, M.Si, Ak, CA (Universitas Mercu Buana Yogyakarta)

Nugraeni, SE, M.Sc (Universitas Mercu Buana Yogyakarta)

Endang Sri Utami, SE, M.Si, Ak, CA (Universitas Mercu Buana Yogyakarta)

Hasim As'ari, SE, MM (Universitas Mercu Buana Yogyakarta)

M. Budiantara, SE, M.Si, Ak, CA (Universitas Mercu Buana Yogyakarta)

Mushawir, M.Si (Universitas Mercu Buana Yogyakarta)

\author{
ADMINISTRASI DAN SIRKULASI \\ Nur Iksan, S. Pd \\ Anis Suci Wulandari, S. Pd \\ ALAMAT REDAKSI \\ Pusat Pengembangan Akuntansi \\ Universitas Mercu Buana Yogyakarta \\ Jalan Wates km. 10 \\ Yogyakarta 55753 \\ Telpon (0274) 6498212 pesawat 145 \\ Fax (0274) 6498213 \\ http://ejurnal.mercubuana-yogya.ac.id/ \\ Email: jurnal.umby@gmail.com
}

Jurnal Riset Akuntansi Mercu Buana (JRAMB) diterbitkan oleh Unit Publikasi Ilmiah \& HaKI Universitas Mercu Buana Yogyakarta, dimaksudkan sebagai media pertukaran informasi dan hasil penelitian antara staf pengajar, alumni, mahasiswa.

JRAMB terbit dua kali setahun.

Redaksi menerima naskah yang belum pernah dipublikasikan. Pedoman penulisan naskah untuk

JRAMB tercantum pada bagian akhir jurnal ini.

Surat-menyurat mengenai artikel yang akan diterbitkan, langganan, keagenan dll, dialamatkan langsung ke alamat redaksi. 


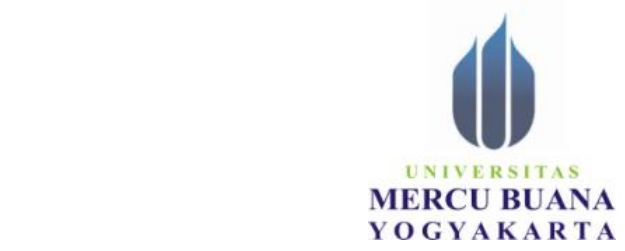

JURNAL RISET AKUNTANSI MERCU BUANA (JRAMB)

Pusat Pengembangan Akuntansi

Universitas Mercu Buana Yogyakarta

Sekretariat: Jalan Wates Km. 10 Yogyakarta, telpon (0274) 6498212 pesawat 144

email: jurnal.umby@gmail.com

web: www.mercubuana-yogya.ac.id

\section{KATA PENGANTAR}

Puji syukur kami panjatkan ke hadirat Tuhan Yang Maha Esa, karena atas berkat rahmat-Nya kami bisa menyelesaikan Jurnal Riset Akuntansi Mercu Buana Edisi Volume 1 Nomor 2 Tahun 2015.

Redaksi mengucapkan terima kasih kepada semua rekan dosen yang telah mengirimkan tulisanya untuk edisi JRAMB kali ini, khususnya kepada para rekan dosen dari Universitas Mataram atas Partisipasinya.

Semoga JRAMB Volume Nomor 2 Tahun 2016 ini dapat memberikan informasi bagi masyarakat dan bermanfaat untuk pengembangan wawasan dan peningkatan ilmu pengetahuan bagi kita semua, Amin 


\section{DAFTAR ISI}

Anggota Redaksi

Kata Pengantar

Daftar Isi

ANALISIS PENGARUH RESTRUKTURISASI KEUANGAN TERHADAP KINERJA PERUSAHAAN (Studi Kasus PT. Elnusa, Tbk)

Hasim As'ari.

DETERMINAN YANG MEMPENGARUHI KUALITAS LABA

PADA PERUSAHAAN MANUFAKTUR DI INDONESIA

(ANALISIS SEBELUM DAN SESUDAH ADOPSI IFRS)

Agus Khazin Fauzi'Endar Pituringsih dan Biana Adha Inapty

ANALISIS PERBANDINGAN KINERJA KEUANGAN

PERUSAHAAN PROSPECTOR DAN DEFENDER (Studi

pada Perusahaan Manufaktur yang Terdaftar di Bursa

Efek Indonesia Periode Tahun 2010-2012)

Erina Sudaryati.

PENGARUH GAYA KEPEMIMPINAN DAN SISTEM

PENGENDALIAN INTERN TERHADAP ANGGARAN BERBASIS

KINERJA PADA BLU UNIVERSITAS MATARAM

Sri Wahyulina' Hermanto dan Biana Adha Inapty.

PENGARUH PRICE EARNING RATIO DAN PRICE TO BOOK VALUE TERHADAP HARGA SAHAM PERUSAHAAN ASURANSI YANG TERDAFTAR DI BURSA EFEK INDONESIA TAHUN 2009-2012

Bayu Rochmad....

REAKSI PASAR ATAS PERUBAHAN SATUAN PERDAGANGAN DAN FRAKSI HARGADI BURSA EFEK INDONESIAPADA TAHUN 2014 (Studi pada Sepuluh Sektor Industri di BEI tahun 2014)

Damper Dwijo Siswoyo dan Endang Sri Utami

ANALISIS PENGARUH CURRENT RATIO, DEBT EQUITY RATIO, EARNING PER SHARE, KURS DAN TINGKAT INFLASI TERHADAP HARGA SAHAM PADA PERUSAHAAN MANUFAKTUR DI LQ45 


\title{
ANALISIS PENGARUH CURRENT RATIO, DEBT EQUITY
}

\section{RATIO, EARNING PER SHARE, KURS DAN TINGKAT INFLASI TERHADAP HARGA SAHAM PADA PERUSAHAAN MANUFAKTUR DI LQ45}

\author{
Ibrahim Nurdin \\ Program Studi Akutansi, Fakultas Ekonomi, Universitas Jendral Sudirman \\ Email : Ibrahimnrdn@yahoo.com
}

\begin{abstract}
ABSTRAK
Penelitian ini merupakan penelitian explanatory yang dilakukan pada sektor manufaktur di LQ45 pada periode 2010-2014. Penelitian ini berjudul "Analisis Pengaruh Current Ratio, Debt Equity Ratio, Earning per Share, Kurs dan Tingkat Inflasi Terhadap Harga Saham pada Perusahaan Manufaktur di LQ45". Tujuan penelitian ini adalah untuk menganalisis pengaruh current ratio, debt equity ratio, earning per share, kurs dan tingkat inflasi terhadap harga saham pada perusahaan manufaktur yang terdaftar di LQ45 tahun 2010-2014. Penelitian ini menggunakan model analisis regresi berganda sebagai alat pengujian hipotesis. Populasi dalam penelitian ini adalah seluruh perusahaan manufaktur yang terdaftar di LQ45 dari tahun 2010 sampai tahun 2014 yaitu sejumlah 12 perusahaan. Sedangkan sampel yang digunakan dalam penelitian ini diambil dengan menggunakan metode purposive sampling. Sehingga sampel akhir dalam penelitian ini berjumlah 7 perusahaan. Dari hasil penelitian didapatkan kesimpulan bahwa debt equity ratio dan earning per share memiliki pengaruh positif terhadap harga saham, sedangkan current ratio, kurs dan tingkat inflasi tidak memiliki pengaruh yang signifikan terhadap harga saham.
\end{abstract}

Kata kunci : harga saham, current ratio, debt equity ratio, earning per share, kurs, tingkat inflasi.

\section{ABSTRACT}

This research is an explanatory research conducted on the manufacturing sector in LQ45 during 2010-2014. The research entitled "Analysis of the Influence of Current Ratio, Debt Equit Ratio, Earning per Share, exchange rate and inflation rate towards Stock price in Manufacture Companies Listed in LQ45". The purpose of this research is to analyze the influence Current ratio, debt equity ratio, earning per share, exchange rate and inflation rate on stock price manufacture companies in LQ45. This research uses multiple regression analysis as model to test the hypothesis. The population in this research are all manufacture companies listed in LQ45 from 2010 until 2014 with the total 12 companies. The samples were taken by using purposive sampling. However, the final samples in this research are 7 companies. The result of this research show that debt equity ratio and earning per share had positive effect on stock price, while current ratio, exchange rate and inflation rate had no significant effect on stock price.

Keywords : stock prices, current ratio, debt equity ratio, earning per share, exchange rate, inflation rate 


\section{PENDAHULUAN}

Pasar modal di Indonesia saat ini sedang berkembang dan terus diminati oleh para investor lokal maupun investor asing. Namun kondisi pasar modal di indonesia tidak selalu stabil melainkan berfluktuasi. Berdasarkan data Ringkasan Statistik dari Otoritas Jasa Keuangan (2014), Indeks Harga Saham pasar modal di Indonesia dari tahun 2009-2012 selalu mengalami kenaikan. Total kenaikan indeks harga saham pada tahun 2009-2012 sebesar $70,33 \%$. Sedangkan pada tahun 2013-2014 Indeks Harga Saham pasar modal di Indonesia mengalami penurunan. Namun penurunan indeks harga saham tersebut relatif tidak signifikan yaitu hanya turun sekitar 0,98\% pada tahun 2013 dan 0,39\% pada tahun 2014.

Pasar modal (capital market) merupakan pasar untuk berbagai instrumen keuangan jangka panjang yang bisa diperjualbelikan, baik surat utang (obligasi), ekuiti (saham), reksa dana, instrumen derivatif maupun instrumen lainnya. Pasar modal juga merupakan sarana pendanaan bagi perusahaan maupun institusi lain (misalnya pemerintah), dan sebagai sarana bagi kegiatan berinvestasi. Dengan demikian, pasar modal memfasilitasi berbagai sarana dan prasarana kegiatan jual beli dan kegiatan terkait lainnya (www.idx.co.id).

Perusahaan-perusahaan yang terdaftar dalam pasar modal di Bursa Efek Indonesia (BEI) saat ini berjumlah 507 perusahaan per 27 Maret 2015 dan dikelompokan sesuai dengan sektornya masing-masing. Salah satu sektor usaha yang berkembang pesat saat ini adalah industri manufaktur. Industri manufaktur adalah industri yang mengolah bahan mentah menjadi barang jadi yang siap dijual. Pemerintah memperkirakan per tumbuhan industri manufaktur nasional pada tahun 2015 mengalami pertumbuhan sebesar $\quad 7,5 \%$ (www.kemenperin.go.id). Hal tersebut menunjukkan pertumbuhan industri manufaktur yang cukup pesat dibandingkan dengan sektor pertanian yang hanya 3,5\%. Hal ini dapat disebabkan oleh tingginya daya beli masyarakat sehingga menyebabkan semakin tinggi pula tingkat produktivitas industri manufaktur. Di dalam pasar modal terdapat berbagai 
macam indeks, salah satunya adalah indeks LQ45, yang merupakan indeks dari 45 perusahaan yang memiliki tingkat likuiditas yang tinggi dan kapitalisasi pasar yang besar, selain itu saham-saham pada perusahaan di indeks LQ45 ini juga aktif diperdagangkan di bursa saham setiap harinya.

Disamping perkembangan pasar modal yang terus meningkat, investasi di pasar modal juga memiliki risiko yang cukup tinggi oleh karena itu sebelum menanamkan modalnya, investor terlebih dahulu harus melihat kinerja perusahaan. Investor tentu hanya akan mena namkan modal pada pe rusahaan yang memiliki kinerja yang baik sehingga dapat memberikan keuntungan bagi penanam modal. Kinerja per usahaan-perusahaan yang sudah go public dapat dilihat dari laporan keuangan yang dipublikasikan untuk umum.

Informasi keuangan merupakan kebutuhan yang penting bagi para investor dalam mengambil keputusan investasi. Selain melihat informasi keuangan perusahaan, investor juga harus memperhatikan harga saham perusahaan yang akan dibelinya. Hal ini dikarenakan investor meng harapkan keuntungan dari investasi tersebut. Menurut Hartono (2008:138) keuntungan yang diperoleh investor dari penanaman modal saham dapat berasal dari laba perusahaan yang dibagikan atau dividen, dan kenaikan atau penurunan harga saham.

Wicaksono (2013) menyatakan peningkatan maupun penurunan harga saham dipegaruhi oleh faktor internal dan eksternal. Faktor internal yang mempengaruhi harga saham antara lain adalah kinerja keuangan perusahaan. Selain itu, faktor eksternal yang mempengaruhi harga pasar antara lain adalah nilai tukar, suku bunga, dan inflasi.

Pengukuran kinerja keuangan perusahaan adalah kemampuan dari suatu perusahaan dalam menggunakan modal yang dimiliki secara efektif dan efisien (Munawir, 2011:50). Kinerja keuangan perusahaan merupakan suatu faktor yang dilihat oleh calon investor untuk menentukan investasi saham. Bagi sebuah perusahaan, menjaga dan meningkatkan kinerja keuangan adalah suatu keharusan agar saham tersebut tetap diminati oleh investor. Kinerja keuangan perusahaan merupakan suatu gambaran tentang 
kondisi keuangan suatu perusahaan yang dianalisis dengan alat-alat analisis keuangan, sehingga dapat diketahui mengenai baik buruknya keadaan keuangan suatu perusahaan yang mencerminkan prestasi kerja dalam periode tertentu.

Kinerja perusahaan dapat diukur dengan berbagai cara, diantaranya dengan rasio keuangan. Rasio keuangan terdiri dari rasio likuiditas, rasio aktivitas, rasio solvabilitas, rasio profitabilitas dan rasio penilaian pasar (Sawir, 2005:7). Dalam penelitian ini, penulis membatasi hanya menggunakan Current Ratio (CR) sebagai ukuran likuiditas, Debt Equity Ratio (DER) sebagai ukuran solvabilitas, dan Earnings Per Share (EPS) sebagai ukuran profitabilitas. Current Ratio digunakan untuk mengetahui kemampuan perusahaan melunasi kewajiban jangka pendeknya dengan aktiva lancar yang dimiliki perusahaan. Debt Equity Ratio digunakan untuk mengukur sejauh mana besarnya utang dapat ditutupi oleh modal sendiri. Utang merupakan salah satu sarana pendanaan bagi perusahaan (Darmadji dan Fakhruddin, 2012:158). Earning Per Share digunakan untuk mengukur kemampuan perusahaan dalam menghasilkan keuntungan bersih dari setiap lembar saham biasa. Kurs atau nilai tukar merupakan harga mata uang domestik terhadap mata uang asing (Simorangkir dan Suseno, 2004:4).

Bagi investor rendahnya perubahan nilai kurs merupakan pertanda baik, ini menunjukkan stabilnya perekonomian suatu negara dan dapat dijadikan lahan investasi. Inflasi menggambarkan kondisi ekonomi dimana terjadinya peningkatan harga produk-produk secara keseluruhan sehingga terjadi penurunan daya beli uang (Tandelilin, 2010:342). Pernyataan tersebut menunjukkan bahwa penurunan inflasi merupakan sinyal baik bagi investor, karena seiring dengan menurunnya risiko daya beli uang dan risiko pendapatan riil. Oleh karena itu, dengan melihat informasi rasio keuangan, kurs dan tingkat inflasi investor dapat mengetahui tingkat keamanan investasi yang akan diperolehnya, sehingga dapat dijadikan acuan oleh investor untuk menilai harga saham perusahaan yang akan dibelinya. Dari uraian latar belakang tersebut, peneliti tertarik untuk melakukan penelitian lebih 
lanjut, dengan judul: "ANALISIS

PENGARUH CURRENT RATIO,

DEBT EQUITY RATIO, EARNINGS

PER SHARE, KURS, DAN TINGKAT

INFLASI TERHADAP HARGA

SAHAM PADA PERUSAHAAN

MANUFAKTUR DI LQ45”.

\section{Rumusan masalah}

Dari uraian latar belakang di atas maka dirumuskan masalah sebagai berikut:

1. Apakah Current Ratio (CR) berpengaruh terhadap harga saham?

2. Apakah Debt Equity Ratio (DER) berpengaruh terhadap harga saham?

3. Apakah Earnings Per Share (EPS) berpengaruh terhadap harga saham?

4. Apakah nilai tukar berpengaruh terhadap harga saham?

5. Apakah tingkat inflasi berpengaruh terhadap harga saham?

\section{Pembatasan Masalah}

1. Penelitian ini menggunakan rasio keuangan untuk melihat pengaruh faktor internal perusahaan terhadap harga saham.

2. Penelitian ini hanya menggunakan 3 rasio keuangan yaitu rasio Likuiditas yang diproksikan dengan Current Ratio, Solvabilitas yang diproksikan dengan Debt Equity Ratio dan Profitabilitas yang diproksikan dengan Earnings Per Share.

3. Proksi yang digunakan pada faktor eksternal perusahaan adalah Kurs dan Tingkat Inflasi.

4. Jenis perusahaan yang dijadikan sebagai sampel dalam penelitian ini adalah perusahaan manufaktur yang terdaftar di indeks LQ45.

5. Tahun pengambilan data untuk menghitung variabel dibatasi hanya 5 tahun, yaitu tahun 2010-2014.

\section{Tujuan penelitian}

Tujuan dari penelitian ini yaitu:

1. Mengetahui pengaruh Current Ratio (CR) terhadap harga saham. 
2. Mengetahui pengaruh Debt Equity Ratio (DER) terhadap harga saham.

3. Mengetahui pengaruh Earnings Per Share (EPS) terhadap harga saham.

4. Mengetahui pengaruh nilai tukar terhadap harga saham.

5. Mengetahui pengaruh tingkat inflasi terhadap harga saham.

\section{Manfaat penelitian}

1. Manfaat teoritis

Hasil dari penelitian ini diharapkan dapat memberikan tambahan referensi untuk akademisi mengenai pengaruh kinerja keuangan dan faktor eksternal seperti nilai tukar, dan tingkat inflasi terhadap harga saham. Selain itu, penelitian ini juga dapat digunakan sebagai acuan riset mendatang.

2. Manfaat praktis

Hasil dari penelitian ini diharapkan dapat menjadi masukan bagi pihak manajemen perusahaan dalam mencapai tujuan perusahaan yaitu memaksimalkan keun tungan dalam penjualan saham.
Serta bagi investor untuk menentukan harga saham sehingga tidak terjadi alokasi kesalahan dana investasi dari perusahaan yang benar-benar prospektif ke perusahaan yang tidak prospektif.

\section{TINJAUAN PUSTAKA}

\section{Telaah Pustaka}

\section{Teori Sinyal}

Teori sinyal (signaling theory) menjelaskan mengapa perusahaan mempunyai dorongan untuk memberikan informasi laporan keuangan kepada pihak eksternal. Dorongan perusahaan untuk memberikan informasi karena terdapat asimetri informasi antara perusahaan dan pihak luar. Perusahaan lebih banyak mengetahui perusahaan dan prospek yang akan datang dari pada pihak luar yaitu investor dan kreditor. Kurangnya informasi pihak luar mengenai perusahaan menyebabkan mereka melindungi diri dengan memberikan harga yang rendah untuk perusahaan. Perusahaan dapat meningkatkan nilai perusahaan engan mengurangi asimetri. Salah satu cara mengurangi informasi asimetri adalah 
dengan memberikan sinyal pada pihak luar (Wolk, Tearney dan Dodd, 2000:81).

\section{Saham}

Menurut Darmadji dan Fakhruddin (2008:30) saham adalah surat berharga yang menunjukkan kepemilikan seorang investor di dalam suatu perusahaan yang artinya jika seseorang membeli saham suatu perusahaan, itu berarti dia telah menyertakan modal ke dalam suatu perusahaan tersebut sebanyak jumlah saham yang dibeli.

\section{Harga Saham}

Harga saham merupakan nilai suatu saham yang mencerminkan kekayaan perusahaan yang mengeluarkan saham tersebut. Secara umum semakin baik keuangan perusahaan dan semakin banyak keuntungan yang dinikmati oleh pemegang saham kemungkinan harga saham akan naik. Tetapi saham yang memiliki tingkat keuntungan yang baik juga bisa mengalami penurunan harga. Berdasarkan fungsinya, harga suatu saham dibagi atas tiga jenis, yaitu sebagai berikut (Anoraga dan Pakarti, 2008:58):

$$
\text { a. Harga nominal }
$$

Yaitu harga yang tercantum pada saham untuk tujuan akuntansi.

b. Harga Dasar

Yaitu harga untuk menentukan nilai dasar, dipergunakan dalam perhitungan indeks harga saham. Harga dasar akan berubah sesuai dengan aksi emiten. Untuk saham baru, harga dasar merupakan harga perdananya.

c. Harga pasar

Yaitu harga pada pasar riil dan merupakan harga yang paling mudah ditentukan karena merupakan harga dari suatu saham pada pasar yang sedang berlangsung atau jika pasar sudah ditutup, maka harga pasar adalah harga penutupannya (closing price).

\section{Current ratio}

Current Ratio merupakan ukuran yang paling umum digunakan untuk mengetahui kesanggupan memenuhi kewajiban jangka pendek karena rasio ini menunjukkan seberapa jauh tuntutan dari kreditor jangka pendek dipenuhi oleh aktiva yang 
diperkirakan menjadi uang tunai dalam periode yang sama dengan jatuh tempo utang.

Current Ratio yang rendah biasanya dianggap menunjukkan terjadinya masalah dalam likuiditas. Sebaliknya suatu perusahaan yang Current Ratio-nya terlalu tinggi juga kurang bagus, karena menunjukkan banyaknya dana menganggur yang pada akhirnya dapat mengurangi kemampuan laba perusahaan (Sawir, 2005: 8). Rumus Current Ratio:

$$
\text { Current Ratio }=\frac{\text { Current Assets }}{\text { Current Liabilites }}
$$

\section{Debt equity ratio}

Rasio ini menggambarkan perbandingan utang dan ekuitas dalam pendanaan perusahaan dan menunjukkan kemampuan modal sendiri perusahaan tersebut untuk memenuhi seluruh kewajibannya (Sawir, 2005:13). Rumus Debt Equity Ratio:

\section{Debt Equity Ratio = $\frac{\text { Total Debt }}{\text { Total Equity }}$}

\section{Earning per share}

Menurut Harahap (2008:306) Earning per share adalah rasio yang menunjukkan berapa besar kemampuan perlembar saham dalam menghasilkan laba. Rasio ini merupakan rasio keuangan yang paling sering dianalisis dan dikutip. Alasan utama Earnings Per Share (EPS) menjadi fokus utama dibandingkan laba adalah karena tujuan perusahaan adalah memaksimalkan kesejahteraan pemegang saham. Rumus Earnings Per Share:

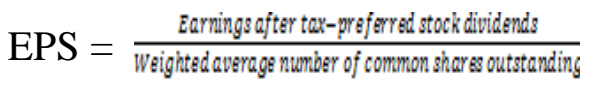

\section{Inflasi}

Inflasi adalah ke cenderungan terjadinya pening katan harga produk-produk secara keseluruhan sehingga terjadi penurunan daya beli masyarakat (Tandelilin, 2010:342). Tingkat inflasi yang tinggi biasanya dikaitkan dengan kondisi ekonomi yang terlalu panas (overheated). Artinya, kondisi ekonomi mengalami permintaan atas produk yang melebihi kapasitas penawaran produknya, sehingga harga-harga cenderung mengalami kenaikan. Akibat dari inflasi secara umum adalah melemahnya daya beli masyarakat karena secara riil tingkat pendapatannya juga menurun (Putong, 2002:254).

\section{Kurs}


Menurut Sukirno (2013:397)

nilai tukar atau kurs mata uang asing menunjukkan harga atau nilai mata uang suatu negara dinyatakan dalam nilai mata uang negara lain. Kurs valuta asing dapat juga didefinisikan sebagai jumlah uang domestik yang dibutuhkan, yaitu banyaknya rupiah yang dibutuhkan untuk memperloeh satu unit mata uang asing.

\section{Indeks LQ45}

Menurut Hartono (2008:101) indeks LQ45 meru pakan indeks yang dibentuk hanya dari 45 persahaan -perusahaan yang saham nya paling aktif diper dagangkan. Pertimbangan-pertimbangan yang mendasari pemilihan saham yang masuk LQ45 adalah likuiditas dan kapitalisasi pasar dengan kriteria sebagai berikut:

a. Selama 12 bulan terakhir, rata-rata transaksi sahamnya masuk dalam urutan 60 terbesar di pasar regular.

b. Selama 12 bulan terakhir, rata-rata nilai kapitalisasi pasarnya masuk dalam urutan 60 terbesar di pasar regular.

c. Telah tercatat di BEI paling tidak 3 bulan.

Indeks LQ45 diperbarui tiap 6 bulan sekali, yaitu pada bulan Februari dan Agustus.

\section{Kerangka Pemikiran}

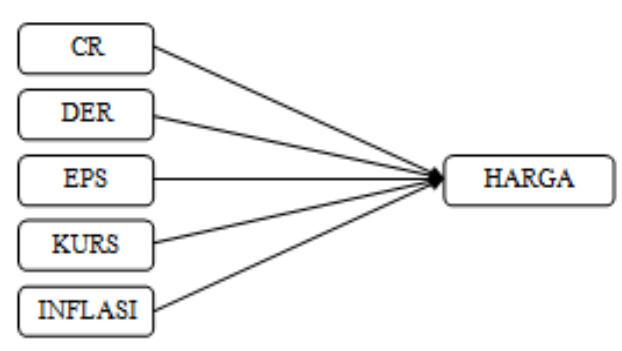

Gambar 1. Kerangka Pemikiran

\section{Hipotesis}

$\mathrm{H}_{1}$ : Current Ratio (CR) berpengaruh positif terhadap harga saham.

$$
\begin{gathered}
\mathrm{H}_{2}: \text { Debt Equity Ratio } \\
\text { berpengaruh positif terhadap } \\
\text { harga saham. }
\end{gathered}
$$

$$
\begin{gathered}
\mathrm{H}_{3} \text { : Earnings Per Share } \\
\text { berpengaruh positif terhadap } \\
\text { Harga Saham. }
\end{gathered}
$$

$\mathrm{H}_{4}$ : Kurs berpegaruh negatif terhadap Harga Saham.

$\mathrm{H}_{5}$ : Tingkat inflasi berpengaruh negatif terhadap Harga Saham. 


\section{METODE PENELITIAN}

\section{Jenis Penelitian}

Penelitian ini merupakan penelitian kuantitatif. Metode yang digunakan dalam penelitian ini adalah studi empiris pada perusahaan manufaktur yang terdaftar di LQ45 dengan menganalisis data laporan keuangan perusahaan dan menganalisis faktor eksternal perusahaan berupa kurs dan tingkat inflasi pada tahun 2010-2014.

\section{Objek Penelitian}

Objek penelitian dalam penelitian ini adalah laporan keuangan tahunan perusahaan manufaktur yang terdaftar dalam LQ45 di Bursa Efek Indonesia (BEI), data harian kurs, data bulanan inflasi dan data harian harga saham pada periode 2010-2014.

\section{Populasi dan sampel}

Populasi yang digunakan dalam penelitian ini adalah perusahaan manufaktur yang terdaftar dalam LQ45 di BEI untuk periode 2010-2014. Teknik pengambilan sampel dengan cara purposive sampling. Purposive sampling adalah teknik penentuan sampel dengan pertimbangan tertentu. Dalam penelitian ini menggunakan sampel perusahaan manufaktur yang terdaftar dalam LQ45 di Bursa Efek Indonesia pada tahun 2010-2014 dengan kriteria perusahaan secara konsisten terdaftar di LQ45 selama tahun 2010-2014.

\section{Jenis dan Sumber Data}

Jenis data dalam penelitian ini adalah data sekunder, yaitu data yang diperoleh secara tidak langsung dari perusahaan melainkan data yang diperoleh dari pihak ketiga. Data sekunder dalam penelitian ini adalah data statistik pada perusahaan manufaktur, data harian kurs, data bulanan inflasi dan data harian harga saham periode 2010 sampai dengan 2014. Data laporan keuangan tahunan perusahaan diperoleh dari http://www.idx.co.id, data harian kurs beserta data bulanan inflasi diperoleh dari http://www.bi.go.id dan data harian harga saham diperoleh dari http://finance.yahoo.com

\section{Teknik Pengumpulan Data}

Teknik pengumpulan data yang digunakan berupa dokumentasi laporan keuangan perusahaan manufaktur yang terdaftar dalam LQ45 di BEI dan laporan tentang nilai tukar dan inflasi tahun 2010 sampai dengan 2014. Selain itu pengumpulan 
data juga berasal dari buku-buku, jurnal, serta sumber data tertulis lainnya yang berhubungan dengan informasi yang dibutuhkan.

\section{Definisi Ko1nseptual dan}

\section{Pengukuran Variabel}

\section{a. Harga saham}

Menurut Anoraga dan Pakarti (2008:58) harga saham merupakan nilai suatu saham yang mencerminkan kekayaan perusahaan yang mengeluarkan saham tersebut. Pergerakan harga saham ditentukan oleh pelaku pasar dan oleh permintaan dan penawaran yang bersangkutan di pasar modal. Data harga saham yang digunakan adalah closing price rata-rata harga saham harian 3 hari sebelum dan sesudah perusahaan mempublikasikan laporan keuangan.

\section{b. Current Ratio (CR)}

Menurut Sawir (2005:8) current ratio adalah rasio yang menunjukkan seberapa jauh tuntutan dari kreditor jangka pendek dapat dipenuhi oleh aktiva yang diperkirakan menjadi uang tunai dalam periode yang sama dengan jatuh tempo utang.

Rasio ini digunakan untuk mengetahui kesanggupan perusahaan memenuhi kewajiban jangka pendeknya. Adapun rumus dari current ratio yaitu:

Current Ratio $=\frac{\text { Current Assets }}{\text { Current Liabilites }}$

c. Debt Equity Ratio (DER)

Menurut Sawir (2005:13) debt equity ratio merupakan rasio yang menggambarkan perbandingan utang dan ekuitas dalam pendanaan perusahaan dan menunjukkan kemampuan modal sendiri perusahaan untuk memenuhi seluruh kewajibannya. Adapun rumus dari debt equity ratio yaitu:

Debt Equity Ratio =

Total Debt

Total Equity

\section{d. Earnings Per Share (EPS)}

Menurut Harahap (2008:306) earning per share adalah rasio yang menunjukkan berapa besar kemampuan perlembar saham dalam menghasilkan laba. Rasio ini mencerminkan laba per lembar saham biasa yang diperoleh 
perusahaan dalam perioda waktu tertentu. EPS merupakan salah satu indikator yang menunjukkan keberhasilan suatu perusahaan. Adapun rumus dari earning per share yaitu:

EPS $=$

Earnings after tax-preferred stock dividends

Weighted average number of common shares outstanding

e. Kurs

Menurut Sukirno (2013:397) nilai tukar atau kurs mata uang asing menunjukkan harga atau nilai mata uang suatu negara dinyatakan dalam nilai mata uang negara lain. Kurs valuta asing dapat juga didefinisikan sebagai jumlah uang domestik yang dibutuhkan, yaitu banyaknya rupiah yang dibutuhkan untuk memperloeh satu unit mata uang asing. Dalam penelitian ini nilai tukar yang diambil adalah nilai tukar rupiah terhadap US Dollar dan diambil dari rata-rata kurs 3 hari sebelum dan sesudah perusahaan mempublikasikan laporan keuangan.

\section{f. Inflasi}

Menurut Tandelilin (2010:342) inflasi adalah kecenderungan terjadinya pe ningkatan harga produk- produk secara kese luruhan sehingga terjadi penurunan daya beli masyarakat. Data inflasi yang digunakan adalah data inflasi bulanan pada bulan perusahaan mempublikasikan laporan keuangannya.

\section{Teknik Analisis Data}

\section{Uji Outlier}

Outlier merupakan kasus atau data yang memiliki karakteristik unik yang terlihat sangat berbeda jauh dari observasi-observasi lainnya dan muncul dalam bentuk nilai ekstrem baik untuk sebuah variabel tunggal maupun variabel kombinasi.

Deteksi terhadap univariate outlier dapat dilakukan dengan menentukan nilai batas yang akan dikategorikan sebagai data outlier yaitu dengan cara mengkonversi nilai data kedalam skor standardized atau yang biasa disebut z-score, yang memiliki rata-rata(means) sama dengan nol dan standar deviasi sama dengan satu. Untuk kasus sampel kecil (kurang dari 80), maka standar skor 
dengan nilai $\pm 2,5$ dinyatakan sebagai data outlier (Ghozali, 2009:40).

\section{Uji asumsi klasik}

Uji asumsi klasik bertujuan untuk mengetahui apakah model regresi tersebut merupakan model regresi yang baik, dalam arti penyimpangannya minimim seperti pada OLS (ordinary Last Square). OLS ini harus sesuai dengan asumsi klasik yang akan menghasilkan unbiased linear estimator dan memiliki varian minimum atau sering disebut BLUE (Blue Linear Uniased Estimated) (Ghozali, 2009:14).

\section{a. Uji Normalitas}

Uji asumsi klasik normalitas merupakan suatu cara yang dimaksudkan untuk menguji apakah nilai residual yang telah distandarisasi pada model regresi berdistribusi normal atau tidak. (Suliyanto, 2011:69). Dalam penelitian ini, uji normalitas dilakukan menggunakan uji statistik non-parametrik

Kolmogorov-Smirnov, dimana uji Kolmogorov-Smirnov merupakan uji normalitas yang menggunakan fungsi distribusi kumulatif. Dalam penelitian ini menggunakan taraf signifikansi (a) sebesar 0,05 (5\%). Data dikatakan bersitribusi normal apabila asymp.significant (2tailed) > 0,05 (alpha).

\section{b. Uji Multikoliniearitas}

Uji multikolonieritas bertujuan untuk menguji apakah model regresi ditemukan adanya korelasi antar variabel bebas. Cara untuk mengetahui apakah terjadi multikolonieritas atau tidak yaitu dengan melihat nilai Tolerance dan Variance Inflation Factor (VIF). Kedua ukuran ini menunjukkan setiap variabel independen manakah yang dijelaskan oleh variabel independen lainnya. Dalam pengertian sederhana setiap variabel independen menjadi variabel dependen (terikat) dan diregresi terhadap variabel independen lainnya. Tolerance mengukur variabilitas variabel independen yang terpilih yang tidak dijelaskan oleh variabel independen lainnya. Jadi nilai 
Tolerance yang rendah sama dengan nilai VIF tinggi (karena $\mathrm{VIF}=1 /$ Tolerance $)$. Nilai cut off yang umum dipakai untuk menunjukkan adanya multikolinearitas adalah nilai Tolerance $<0,10$ atau sama dengan nilai $\mathrm{VIF}>10$ (Suliyanto, 2011:90).

\section{c. Uji Heteroskesdatisitas}

Uji ini bertujuan untuk menguji apakah dalam model regresi terjadi ketidaksamaan varians dari residual satu pengamatan ke pengamatan lain (Ghozali, 2009:125). Dalam penelitian ini menggunakan uji Glejser. Uji glejser yaitu meregresikan seluruh variabel independen terhadap variabel dependen. Apabila terdapat variabel independen yang berpengaruh secara signifikan terhadap residual absolute maka dalam model penelitian tersebut terdapat masalah hete roskedastisitas. Gejala hete roskedastisitas ditunjukkan oleh koefisien regresi dari masing-masing variabel bebas terhadap nilai absolut resi dualnya |e|. Jika nilai pro babilitasnya lebih besar dari nilai alpha (Sig. $>\alpha$ ), maka dapat dipastikan model tidak mengandung gejala heteros kedastis atau dikatakan tidak terjadi heteroskedastisitas apa bila $\mathrm{t}$ hitung $<\mathrm{t}$ tabel (Suliyanto, 2011:102).

\section{d. Uji Autokorelasi}

Uji ini dilakukan untuk mengetahui apakah ada korelasi antara anggota serangkaian data observasi yang diuraikan menurut waktu atau ruang (Suliyanto, 2011:125). Salah satu cara untuk mengetahui apakah ada tidaknya autokorelasi dalam model regresi adalah dengan melakukan uji Run test.

Uji Run test merupakan salah satu analisis non-paramterik yang dapat digunakan untuk menguji apakah antar residual terdapat korelasi yang tinggi. Jika antar residual tidak terdapat korelasi maka dikatakan bahwa nilai residual adalah acak atau random. Run test digunakan untuk melihat apakah data residual terjadi 
secara random atau tidak (sistematis). Apabila nilai Asymp. Sig. (2-tailed $)>\alpha(0,05)$ maka tidak terdapat gejala autokorelasi dalam persamaan regresi (Suliyanto, 2011:140).

\section{Analisis Regresi Berganda}

\section{a. Persamaan Regresi}

Analisis regresi berganda adalah analisis yang menghubungkan lebih dari dua variabel untuk mengetahui besarnya pengaruh dari perubahan satu variabel terhadap variabel lainnya. Analisis pengaruh faktor internal yaitu Current Ratio, Debt Equity Ratio dan Earnings Per Share dan faktor eksternal perusahaan yaitu

\section{b. Uji koefisien Determinasi $\left(\mathbf{R}^{2}\right)$}

\section{Menurut Suliyanto} (2011:55) koefisien determinasi merupakan besarnya kontribusi variabel bebas terhadap variabel tergantungnya. Semakin tinggi koefisien determinasi, semakin tinggi kemampuan variabel bebas dalam menjelaskan variasi perubahan pada variabel tergantungnya.
Kurs dan Tingkat inflasi terhadap harga saham persamaan regresinya adalah sebagai berikut:

$$
\begin{aligned}
Y= & \alpha+\beta_{1} \cdot X_{1}+\beta_{2} \cdot X_{2}+ \\
& \beta_{3} \cdot X_{3}+\beta_{4} \cdot X_{4}+\beta_{5} \cdot X_{5} \\
+ & \varepsilon
\end{aligned}
$$

Keterangan:

$\mathrm{Y}=$ Harga saham

$\alpha=$ Koefisien

konstanta

$\beta=$ Koefisien variabel independen

$\mathrm{X}_{1}=$ Current Ratio

$\mathrm{X}_{2}=$ Debt Equity Ratio

$\mathrm{X}_{3}=$ Earnings $\mathrm{Per}$

Share

$\mathrm{X}_{4}=$ Kurs

$\mathrm{X}_{5}=$ Tingkat inflasi

$\varepsilon=$ Standar error

\section{Pengujian hipotesis}

Dalam penelitian ini untuk pengujian hipotesis digunakan Uji Goodness of fit (Uji F) dan Uji t. Penjelasan dari masing-masing uji diatas sebagai berikut:

a) Uji F

Menurut Ghozali (2009:16)

Uji F pada dasarnya menunjukkan apakah semua variabel independen yang dimasukkan dalam model 
mempunyai pengaruh bersama-sama atau simultan terhadap variabel dependen.

Pengujian dilakukan dengan langkah sebagai berikut:

i. Penetapan hipotesis

Ho : Current ratio, debt equity ratio, earning per share, kurs dan tingkat inflasi tidak berpengaruh secara simultan terhadap harga saham.

Ha : Current ratio, debt equity ratio,
earning per share,
kurs dan tingkat
inflasi berpengaruh
secara simultan
terhadap
saham.

ii. Menentukan tingkat signifikansi

Tingkat signifikansi penelitian $(\alpha)=0,05$ dan derajat kebebasan $=(\mathrm{k}-1$, $\mathrm{n}-\mathrm{k})$.

iii. Perhitungan $\mathrm{F}_{\text {hitung }}$ iv.
$F=\frac{\frac{R^{2}}{k-1}}{\frac{1-R^{2}}{n-k}}$

Keterangan :

$$
\mathrm{F} \quad=\text { Nilai } \mathrm{F} \text { hitung }
$$$$
R^{2}=\text { Koefisien }
$$

Determinasi

$k=$ Jumlah variabel

$n=$ Jumlah pengamatan (ukuran sampel)

v. Kriteria pengujian

a. Jika $F_{\text {hitung }} \leq F_{\text {tabel }}$ maka Ho diterima.

b. Jika $F_{\text {hitung }}>F_{\text {tabel }}$ maka Ho ditolak.

vi. Kesimpulan

Nilai $F$ tabel yang diperoleh dibanding dengan nilai $F$ hitung, apabila $\mathrm{F}$ hitung lebih besar dari $\mathrm{F}$ tabel, maka Ho ditolak sehingga dapat disimpulkan bahwa ada pengaruh secara simultan antara kelima variabel independen terhadap variabel dependen.

\section{b) Uji t}

Uji t digunakan untuk menguji apakah ada pengaruh secara parsial antara variabel independen terhadap variabel 
dependen. Suatu variabel

akan memiliki pengaruh yang berarti jika nilai $t$ hitung variabel tersebut lebih besar dibandingkan dengan nilai $\mathrm{t}$ tabel dengan derajat kebebasan $\mathrm{df}=(\mathrm{n}-\mathrm{k})$ dan dalam penelitian ini digunakan $\alpha=5 \% \quad(0,05)$. Adapun penetapan hipotesis dan kriteria pengujiannya adalah sebagai berikut:

i. Penetapan hipotesis

a) Ho : $\beta_{1} \leq 0$, Current ratio tidak berpengaruh positif terhadap harga saham.

Ha : $\beta_{1}>0$, Current ratio berpengaruh positif terhadap harga saham.

b) Ho : $\beta_{2} \leq 0$, Debt equity ratio tidak berpengaruh positif terhadap harga saham.

Ha : $\beta_{2}>0$, Debt equity ratio berpengaruh positif terhadap harga saham.

c) Ho : $\beta_{3} \leq 0$, Earning per share tidak berpengaruh positif terhadap harga

saham.

$\mathrm{Ha}: \beta_{3}>0$, Earning per share berpengaruh positif terhadap harga saham.

d) Ho : $\beta_{4} \geq 0$, Kurs tidak berpengaruh negatif terhadap harga saham. $\mathrm{Ha}: \quad \beta_{4}<0$, Kurs berpengaruh negatif terhadap harga saham.

e) Ho : $\beta_{5} \geq 0$, Tingkat inflasi tidak berpengaruh negatif terhadap harga saham. Ha $: \beta_{5}<0$, Tingkat inflasi berpengaruh negatif terhadap harga saham.

ii. Kriteria pengujian

a) Hipotesis positif Jika $\mathrm{t}_{\text {hitung }} \leq \mathrm{t}_{\text {tabel }}$ atau Sig. >0,05 maka Ho diterima

Jika $t_{\text {hitung }}>\mathrm{t}_{\text {tabel }}$ atau Sig. $\leq 0,05$ maka Ha diterima

b) Hipotesis negatif Jika $t_{\text {hitung }} \geq-t_{\text {tabel }}$ atau Sig. >0,05 maka Ho diterima 
Jika $\mathrm{t}_{\text {hitung }}<-\mathrm{t}_{\text {tabel }}$ atau Sig. $\leq 0,05$ maka Ha diterima

Untuk menghitung nilai t hitung dapat digunakan rumus sebagai berikut (Suliyanto, 2011:62):

$$
t=\frac{b j}{S b j}
$$

Keterangan :

$$
\begin{aligned}
\mathrm{t} & =\text { Nilai } \mathrm{t} \text { hitung } \\
\mathrm{bj}= & \text { Koefisien regresi } \\
\mathrm{Sbj}= & \text { Kesalahan baku } \\
& \text { koefisien regresi }
\end{aligned}
$$

\section{HASIL DAN PEMBAHASAN}

\section{Gambaran Umum Penelitian}

Penelitian ini mengkaji pengaruh faktor internal dan eksternal perusahaan terhadap harga saham pada tahun 2010-2014. Faktor internal yang digunakan dalam penelitian ini menggunakan rasio keuangan, adapun rasio keuangan yang digunakan adalah rasio likuiditas, solvabilitas dan profitabilitas yang masing-masing diproksikan dengan current ratio, debt equity ratio dan earnings per share. Faktor eksternal yang digunakan dalam penelitian ini diproksikan dengan nilai tukar rupiah terhadap dollar amerika dan juga tingkat inflasi. Populasi pada penelitian ini adalah perusahaan manufaktur yang terdaftar dalam indeks LQ45 pada tahun 2010-2014. Hal ini dikarenakan perusahaan yang termasuk dalam indeks LQ45 merupakan perusahaan dengan nilai likuiditas dan nilai kapitalisasi pasar yang tinggi dan juga saham pada perusahaan yang terdaftar dalam indeks LQ45 ini aktif diperdagangkan setiap harinya di pasar modal.

Pengambilan sampel yang digunakan dalam penelitian ini yaitu menggunakan purposive sampling dengan kriteria perusahaan yang secara konstan terdaftar dalam indeks LQ45 selama tahun 2010-2014. Berdasarkan kriteria, maka jumlah sampel yang digunakan dalam penelitian ini ada 7 perusahaan dan jumlah data yang digunakan dalam penelitian ini sebanyak 35 data yang didapat dari $7 \times 5$ (perkalian antara jumlah sampel dengan jumlah tahun dalam pengamatan). Daftar kode emiten dan nama perusahaan sampel valid yang digunakan dalam penelitian dapat dilihat pada lampiran 1 .

\section{Analisis Data}

\section{Analisis Statistik Deskriptif}


Analisis statistik deskriptif dalam penelitian ini terdiri dari Current ratio, Debt equity ratio,
Earnings per share, Kurs, Tingkat

inflasi dan Harga saham.

Tabel 1. Hasil Analisis Deskriptif

Descriptive Statistics

\begin{tabular}{lcrrrr}
\hline Keterangan & $\mathrm{N}$ & $\begin{array}{c}\text { Minimu } \\
m\end{array}$ & Maximum & \multicolumn{1}{c}{ Mean } & $\begin{array}{c}\text { Std. } \\
\text { Deviation }\end{array}$ \\
\hline Current Ratio & 35 & 0,67 & 6,99 & 2,54 & 1,675 \\
$\begin{array}{l}\text { Debt Equity Ratio } \\
\text { Earnings per }\end{array}$ & 35 & 0,15 & 2,14 & 0,74 & 0,570 \\
Share & 35 & 28,45 & $4.393,14$ & $1.077,12$ & $1.018,697$ \\
Kurs & & & & & \\
Inflasi & 35 & $8.646,00$ & $13.185,00$ & $10.446,94$ & $1.649,817$ \\
Harga Saham & 35 & 3,56 & 7,75 & 5,92 & 1,188 \\
\hline
\end{tabular}

Hasil analisis deskriptif pada variabel Current ratio diperoleh rata-rata sebesar 2,54 dengan nilai terendah sebesar 0,67 dan nilai tertinggi sebesar 6,99. Suatu perusahaan yang memiliki current ratio terlalu rendah biasanya dianggap memiliki masalah dalam likuiditas. Sebaliknya suatu perusahaan yang current rationya terlalu tinggi juga kurang bagus, karena menunjukkan banyaknya dana menganggur yang pada akhirnya dapat mengurangi kemampuan laba perusahaan. Rasio yang ideal ditentukan oleh rule of thumb (ketentuan umum) dengan mempertimbangkan beberapa faktor seperti jenis industri dan kebiasaan kredit (Sawir, 2005:8).
Rata-rata Debt equity ratio sebesar 0,74 dengan nilai terendah sebesar 0,15 dan nilai tertinggi sebesar 2,14 . Perusahaan yang memiliki nilai debt equity ratio yang terlalu tinggi maka perusahaan itu juga memiliki risiko keuangan yang tinggi pula. Angka 2,14 merupakan debt equity ratio perusahaan unilever pada tahun 2013 yang mana angka ini relatif tinggi karena perusahaan menggunakan utang sebagai sumber terbesar pendanaan modalnya.

Rata-rata Earnings per share sebesar 1.077,12 dengan nilai terendah sebesar 28,45 dan nilai tertinggi sebesar 4.393,14. Nilai 28,45 merupakan nilai earning per share perusahaan Kalbe Farma yang pada 
tanggal 8 Oktober 2012 melakukan stock split (pemecahan saham) menjadi $1 / 5$ sehingga nilai earning per share mengalami penurunan karena meningkatnya jumlah saham yang diedarkan oleh perusahaan tersebut. Angka 4.393,14 merupakan nilai erarning per share perusahaan Astra Internasional yang memang relatif cukup tinggi dikarenakan perusahaan tersebut memiliki laba yang tinggi pula.

Rata-rata kurs sebesar 10.446,94 dengan nilai terendah sebesar 8.646 pada tahun 2010 dan nilai tertinggi sebesar 13.185 pada tahun 2014. Nilai rupiah terhadap $U S$ dollar tiap tahunnya selalu melemah, Laporan Perekonomian Indonesia tahun 2014 yang diterbitkan oleh Bank Indonesia mengungkapkan bahwa pada triwulan IV 2014, tekanan terhadap Rupiah meningkat dipengaruhi oleh indeks $U S$ Dollar yang terus menguat. Ekonomi Amerika Serikat yang membaik ditengah pemulihan global yang berjalan lambat mendorong peningkatan permintaan $U S$ dollar sebagai safe haven assets. Rata-rata inflasi sebesar 5,92 dengan nilai terendah sebesar 3,56 pada bulan Februari 2012 dan nilai tertinggi sebesar 7,75 pada bulan Februari 2014. Nilai tersebut masih dalam kategori inflasi ringan, yang mana tingkat inflasinya wajar terjadi pada negara berkembang. Rata-rata harga saham sebesar 21.098,57 dengan nilai terendah sebesar 1.247 dan nilai tertinggi sebesar 69.730 .

\section{Uji Outlier}

Pada data dalam penelitian ditemukan adanya dua nilai outlier yaitu data harga saham ASII pada tahun 2011 dengan nilai $z$-score 2,60 dan data current ratio INTP pada tahun 2011 dengan nilai z-score 2,66. Kemudian data tersebut dihapus dalam penelitian sehingga total data yang digunakan dalam penelitian adalah sebanyak 33 data.

\section{Uji Asumsi Klasik}

\section{a. Uji Normalitas}

Uji normalitas ini menggunakan uji non-parametrik Kol mo gorov-Smirnov. Berdasarkan lampiran 5 diperoleh nilai asymp.significant (2-tailed) sebesar 0,057. Hal ini menunjukkan bahwa data penelitian terdistribusi secara normal karena nilai 
asymp.significant (2tailed) >

alpha (0,05).

b. Uji Multikolinearitas
Hasil uji Multikolinearitas pada penelitian ini dapat dilihat pada tabel 2 .

Tabel 2. Hasil Uji Multikolinearitas

\begin{tabular}{lccc}
\hline \multicolumn{1}{c}{ Variabel } & Tolerance & VIF & Keterangan \\
\hline Current ratio & 0,424 & 2,358 & Bebas Mulitikolinearitas \\
Debt equity ratio & 0,422 & 2,371 & Bebas Mulitikolinearitas \\
Earnings per share & 0,985 & 1,015 & Bebas Mulitikolinearitas \\
Kurs & 0,711 & 1,406 & Bebas Mulitikolinearitas \\
Inflasi & 0,716 & 1,397 & Bebas Mulitikolinearitas \\
\hline
\end{tabular}

Tabel 2 menjelaskan tentang hasil pengujian multikolinearitas yaitu bahwa semua variabel penelitian menghasilkan nilai tolerance $>0,1$ dan nilai VIF <

c. Uji Heteroskedastisitas
10 yang berarti tidak ada korelasi antar variabel bebas. Jadi dapat disimpulkan bahwa model penelitian ini tidak terdapat gejala multikolinearitas.

Hasil uji heteroskedastisitas dapat dilihat pada tabel 3 .

Tabel 3. Hasil Uji Heteroskedastisitas

\begin{tabular}{lccc}
\hline \multicolumn{1}{c}{ Variabel } & $\mathrm{t}$ & Sig. & Keterangan \\
\hline Current ratio & $-0,678$ & 0,504 & Bebas Heteroskedastisitas \\
Debt equity ratio & 0,499 & 0,622 & Bebas Heteroskedastisitas \\
Earnings per & 1.528 & 0,138 & Bebas Heteroskedastisitas \\
share & 0,366 & 0,717 & Bebas Heteroskedastisitas \\
Kurs & $-0,473$ & 0,640 & Bebas Heteroskedastisitas \\
Inflasi & & & \\
\hline
\end{tabular}

Tabel 3 menjelaskan tentang hasil pengujian heteros kedastisias yaitu bahwa nilai sig. untuk masing-masing variabel adalah lebih besar dari alpha $(0,05)$. Maka dapat disimpulkan semua variabel dalam penelitian ini tidak terdapat gejala heteroskedastisitas.

\section{d. Uji Autokorelasi}

Hasil uji autokorelasi dapat dilihat pada tabel 4. 
Tabel 4. Hasil Uji Autokorelasi dengan Runs Test

Unstandardized Residual

Test Value

Cases < Test Value

$-559,502$

Cases > = Test

Value

Total Cases

Number of Runs

Z

Asymp.

Sig.

0,155

(2-tailed)

Hasil pengujian pada tabel 4

diatas, dapat dilihat bahwa nilai Asymp. Sig. (2-tailed) sebesar

0,155 yang berarti lebih besar

\section{Analisis Regresi Berganda}

\section{a. Persamaan Regresi}

Pada penelitian ini, analisis regresi berganda digunakan untuk menguji pengaruh variabel bebas dari nilai alpha $(0,05)$. Maka dapat disimpulkan bahwa tidak terdapat gejala autokorelasi pada model regresi yang digunakan.

Tabel 5. Hasil Analisis Regresi Berganda

\begin{tabular}{lrrrr}
\hline \multicolumn{1}{c}{ Model } & $\begin{array}{r}\text { Koefisien } \\
\text { regresi }\end{array}$ & t hitung & Sig. \\
\hline Current ratio & 892,624 & 0,698 & 0,491 \\
Debt equity ratio & $9.670,685$ & 2,860 & 0,008 \\
Earnings per share & & 18,170 & 12,213 & 0,000 \\
Kurs & & 0,142 & 0,158 & 0,875 \\
Inflasi & & $-689,131$ & $-0,502$ & 0,619 \\
\hline Konstanta & $=$ & $-3.469,923$ & & \\
Adjusted $\mathrm{R}^{2}$ & $=$ & 0,826 & & \\
$\mathrm{~F}_{\text {hitung }}$ & $=$ & 31,481 & & \\
$\mathrm{~F}_{\text {tabel }}$ & $=$ & 2,503 & & \\
$\mathrm{~F}_{\text {sig. }}$ & $=$ & 0,000 & & \\
\hline
\end{tabular}

Dari tabel 5 dapat diketahui

$-3.469,923+892,624 X_{1}+9.670,685$

persamaan regresi sebagai berikut:

$\mathrm{X}_{2}+18,17 \mathrm{X}_{3}+0,142 \mathrm{X}_{4}-689,131$ 
$\mathrm{X}_{5}$ Interpretasi dari hasil persamaan egresi berganda dapat diuraikan sebagai berikut:

i. Konstanta (a) sebesar $-3.469,923$ memiliki arti bahwa apabila variabel current ratio, debt equity ratio, earnings per share, kurs dan inflasi bernilai nol maka variabel harga saham akan turun sebesar 3.469,923.

ii. Variabel current ratio memiliki nilai koefisiensi sebesar 892,624. Nilai ini mempunyai arti apabila current ratio naik sebesar $1 \%$, maka harga saham akan naik sebesar Rp 892,624 apabila variabel lain dianggap konstan.

iii. Variabel debt equity ratio memiliki nilai koefisiensi sebesar 9.670,685. Nilai ini mempunyai arti apabila debt equity ratio naik sebesar $1 \%$, maka harga saham akan naik sebesar Rp 9.670,685 apabila variabel lain dianggap konstan.

iv. Variabel earnings per share memiliki nilai koefisiensi sebesar 18,17. Nilai ini mempunyai arti apabila earnings per share naik sebesar Rp 1, maka harga saham akan naik sebesar $\mathrm{Rp}$ 18,17 apabila variabel lain dianggap konstan.

v. Variabel kurs memiliki nilai koefisiensi sebesar 0,142. Nilai ini mempunyai arti apabila kurs naik sebesar Rp 1, maka harga saham akan naik sebesar Rp 0,142 apabila variabel lain dianggap konstan.

vi. Variabel inflasi memiliki nilai koefisiensi sebesar $-689,131$. Nilai ini mempunyai arti apabila inflasi naik sebesar $\mathrm{Rp}$ 1, maka harga saham akan turun sebesar $\mathrm{Rp} \quad 689,131$ apabila variabel lain dianggap konstan.

\section{b. Uji Koefisien Determinasi $\left(\mathbf{R}^{\mathbf{2}}\right)$}

Hasil uji koefisien determinasi pada tabel 5 menjelaskan besar nilai adjusted $\mathrm{R}^{2}$ sebesar 0,826 yang berarti variabilitas variabel dependen yang dapat dijelaskan oleh variabel independen sebesar $82,6 \%$. Sisanya sebesar $17,4 \%$ dijelaskan oleh variabel lain yang tidak diteliti dalam penelitian ini. 


\section{Pengujian Hipotesis}

\section{a. Uji F}

Hasil pengujian $F_{\text {hitung }}$ pada tabel 5 di atas diperoleh nilai $\mathrm{F}$ sebesar 31,481 yang lebih besar dari $F_{\text {tabel }} 2,503$ dengan signifikansi 0,000 yang nilainya lebih kecil dari 0,05 . Ini menunjukkan bahwa model penelitian cocok (fit) dan berarti current ratio, debt equity ratio, earnings per share, kurs dan inflasi secara simultan berpengaruh terhadap harga saham.

\section{b. Uji t}

Uji $t$ digunakan untuk menguji apakah ada pengaruh secara parsial antara variabel independen terhadap variabel dependen. Dengan menggunakan tingkat kesalahan $5 \%(\alpha=0,05)$ dan degree of freedom (n-k) diperoleh $\mathrm{t}$ tabel sebesar 1,703. Berdasarkan hasil pengujian secara parsial pada Tabel 5 dapat disimpulkan bahwa:

1.) Variabel current ratio memiliki nilai t hitung $0,698<$ t tabel 1,703 dan sig. 0,491 > alpha $(0,05)$ sehingga Ho diterima. Hal ini menunjukkan bahwa hipotesis yang menyatakan current ratio berpengaruh positif terhadap harga saham ditolak.

2.) Variabel debt equity ratio memiliki nilai t hitung 2,860> t tabel 1,703 dan sig. 0,008 < alpha $(0,05)$ sehingga Ho ditolak. Hal ini menunjukkan bahwa hipotesis yang menyatakan debt equity ratio berpengaruh positif terhadap harga saham diterima.

3.) Variabel earnings per share memiliki nilai t hitung 12,213 $>\mathrm{t}$ tabel 1,703 dan sig. $0,000<$ alpha $(0,05)$ sehingga Ho ditolak. Hal ini menunjukkan bahwa hipotesis yang menyatakan earnings per share berpengaruh positif terhadap harga saham diterima.

4.) Variabel kurs memiliki nilai $\mathrm{t}$ hitung $0,158>\mathrm{t}$ tabel $-1,703$ dan sig. 0,875 > alpha $(0,05)$ sehingga Ho diterima. Hal ini menunjukkan bahwa hipotesis yang menyatakan kurs berpengaruh negatif terhadap harga saham ditolak.

5.) Variabel tingkat inflasi memiliki nilai $\mathrm{t}$ hitung $-0,502>\mathrm{t}$ tabel $-1,703$ dan sig. 0,619> alpha $(0,05)$ sehingga Ho diterima. Hal 
ini menunjukkan bahwa hipotesis yang menyatakan tingkat inflasi berpengaruh negatif terhadap harga saham ditolak.

\section{HASIL DAN PEMBAHASAN}

\section{Current ratio tidak berpengaruh} terhadap harga saham

Hasil pengujian hipotesis tidak ditemukan adanya pengaruh signifikan antara current ratio terhadap harga saham. Ini menunjukkan bahwa harga saham perusahaan pada sampel yang diteliti tidak dipengaruhi secara langsung oleh current ratio perusahaan itu sendiri. Kemampuan perusahaan dalam melunasi kewajiban jangka pendek perusahaan tidak begitu berpengaruh terhadap laba perusahaan yang nantinya akan dibagikan kepada investor, sehingga tidak mempengaruhi minat investor untuk berinvestasi pada saham. Oleh karena itu, investor tidak begitu mempertimbangkan current ratio sebagai pertimbangan untuk berinvestasi pada saham perusahaan tersebut.

Penyebab lain mengapa current ratio tidak berpengaruh terhadap harga saham adalah karena tingkat likuiditas dari saham pada perusahaan indeks LQ45 sendiri dikategorikan sebagai saham dengan likuiditas tinggi. Sehingga investor yang menginvestasikan dananya pada saham di perusahaan ini tidak lagi mempertimbangkan tingkat likuiditas perusahaan.

\section{Debt equity ratio berpengaruh}

\section{positif terhadap harga saham}

Hasil pengujian hipotesis ditemukan adanya pengaruh positif signifikian antara debt equity ratio terhadap harga saham. Hal tersebut menunjukan bahwa naiknya debt equity ratio akan diikiuti dengan harga saham yang meningkat pula.

Menurut Sawir

(2005:11) dijelaskan bahwa perusahaan yang menggunakan utang akan lebih beresiko daripada perusahaan tanpa utang, karena selain mempunyai resiko bisnis, perusahaan yang menggunakan utang mempunyai resiko keuangan. Namun resiko utang tersebut akan meningkatkan laba perusahaan, karena perusahaan mendapatkan tambahan modal.

$$
\text { Hasil penelitian ini }
$$
menunjukkan bahwa perusahaan dapat 
mengelola dengan baik dana yang berasal dari hutang untuk mendanai aktivanya sehingga berdampak pada nilai perusahaan. Hal ini juga konsisten dengan teori Brigham dan Houston (2001:84) yang menyatakan jika perusahaan memperoleh pengembalian yang lebih besar atas investasi yang dibiayai dengan dana pinjaman dibandingkan dengan pembayaran bunga maka pengembalian atas modal pemilik akan lebih besar yang dapat menaikkan nilai perusahaan.

Hasil penelitian ini sejalan dengan penelitian sebelumnya yang dilakukan oleh Patar, Darminto dan Saifi (2014) yang mengungkapkan bahwa debt equity ratio memiliki pengaruh positif signifikan terhadap harga saham.

\section{Earnings per share berpengaruh positif terhadap harga saham}

Hasil pengujian hipotesis ditemukan adanya pengaruh positif signifikan antara earnings per share terhadap harga saham. Hal ini menunjukkan earnings per share memiliki pengaruh positif bagi harga saham. Tandelilin (2001:241) berpendapat jika earnings per share merupakan komponen pertama yang harus dinilai untuk menilai kinerja suatu saham, sehingga seharusnya earnings per share menjadi variabel yang berpengaruh signifikan terhadap harga saham.

Implikasinya adalah pengetahuan investor tentang earnings per share sangat penting untuk melakukan penilaian berapa perkiraan potensi pendapatan yang dapat diterima jika membeli suatu saham. Earnings per share merupakan jumlah laba atau keuntungan yang diperoleh investor dalam satu periode untuk tiap lembar saham yang dimilikinya. Earnings per share juga merupakan gambaran mengenai kemampuan perusahaan dalam menghasilkan keuntungan bersih dalam setiap lembar saham. Earnings per share yang meningkat menandakan bahwa perusahaan tersebut berhasil meningkatkan taraf kemakmuran investor. Hal ini mendorong investor untuk menambah jumlah modal yang ditanamkan pada saham perusahaan tersebut. Peningkatan jumlah permintaan terhadap saham mendorong harga saham naik. Dengan demikian jika earnings per share meningkat maka pasar akan merespon 
positif dengan diikuti kenaikan harga saham. Hasil dari analisis penelitian ini sesuai dengan penelitian sebelumnya yang dilakukan oleh Dewi dan Suaryana (2013) yang mengatakan bahwa earnings per share memiliki pengaruh positif signifikan terhadap harga saham.

\section{Kurs tidak berpengaruh}

\section{signifikan terhadap harga saham}

Hasil pengujian hipotesis tidak ditemukan adanya pengaruh yang signifikan antara kurs terhadap harga saham. Walaupun tidak memiliki pengaruh yang signifikan namun kurs memiliki pengaruh positif terhadap harga saham yang berarti jika kurs rupiah terhadap US dollar naik (melemah) maka akan meningkatkan harga saham. Hal ini terjadi karena perusahaan yang dijadikan sampel merupakan perusahaan manufaktur yang sudah multinasional sehingga apabila nilai rupiah melemah maka perusahaan akan melakukan ekspor yang kemudian akan meningkatkan laba perusahaan. Berdasarkan penelitian data kurs dari tahun ke tahun selalu mengalami kenaikan, artinya nilai rupiah terdepresiasi secara terus menerus. Kenaikan yang bersifat terus menerus selama periode penlitian ini menyebabkan investor tidak begitu mempertimbangkan variabel kurs dalam keputusan berinvestasi dengan asumsi bahwa kurs akan selalu naik dari tahun ke tahun, dan lebih memper timbangkan faktor lainnya sebagai bahan pertimbangan melakukan investasi seperti informasi keuangan perusahaan. Hal ini sejalan dengan penelitian yang dilakukan oleh Patar, Darminto dan Saifi (2014) yang mengatakan kurs tidak berpengaruh signifikan terhadap harga saham.

\section{Tingkat inflasi tidak}

berpengaruh signifikan terhadap

\section{harga saham}

Hasil pengujian hipotesis tidak ditemukan adanya pengaruh yang signifikan antara tingkat inflasi terhadap harga saham. Hal ini disebabkan oleh perubahan tingkat inflasi yang masih berada dibawah $10 \%$ atau masih dalam kategori inflasi ringan (www.artikelsiana.com), yang mana tingkat inflasinya wajar terjadi pada negara berkembang yang selalu berada dalam proses pembangunan sehingga pasar masih bisa menerima tingkat inflasi yang terjadi selama 
periode penelitian, sehingga tidak mempengaruhi investor dalam pengambilan keputusan untuk berinvestasi. Hal ini sejalan dengan penelitian yang dilakukan Wicaksono (2013) yang mengatakan tingkat inflasi tidak berpengaruh signifikan terhadap harga saham.

\section{KESIMPULAN}

Kesimpulan dalam penelitian ini adalah sebagai berikut: Current ratio tidak berpengaruh signifikan terhadap harga saham perusahaan manufaktur ng terdaftar dalam LQ45 pada tahun 2010-2014.

1. Debt equity ratio berpengaruh positif signifikan terhadap harga saham perusahaan manufaktur yang terdaftar dalam LQ45 pada tahun 2010-2014.

2. Earnings per share berpengaruh positif signifikan terhadap harga saham perusahaan manufaktur yang terdaftar dalam LQ45 pada tahun 2010-2014.

3. Kurs tidak berpengaruh signifikan terhadap harga saham perusahaan manufaktur yang terdaftar dalam LQ45 pada tahun 2010-2014.
4. Tingkat inflasi tidak berpengaruh signifikan terhadap harga saham perusahaan manufaktur yang terdaftar dalam LQ45 pada tahun 2010-2014.

\section{DAFTAR PUSTAKA}

Amanda, Astrid., Darminto, dan Achmad Husaini. 2013. Pengaruh Debt to Equity Ratio, Return on Equity, Earnings Per Share, dan Price Earning ratio terhadap Harga Saham. Jurnal Fakultas Ilmu Administrasi Universitas Brawijaya: 1-11.

Amin, Muhammad Zuhdi. 2012. Pengaruh Tingkat Inflasi, Suku bunga SBI, Nilai Kurs Dollar dan Indeks Dow Jones terhadap Pergerakan Indeks Harga Saham Gabungan di BEI periode 2008-2011. Jurnal Fakultas Ekonomi dan Bisnis Universitas Brawijaya: 4-5.

Amperaningrum, Izzati dan Robby Suryawan Agung. 2011. Pengaruh Tingkat Suku Bunga SBI, Nilai Tukar Mata Uang dan Tingkat Inflasi Terhadap 
Perubahan Harga Saham Sub

Sektor Perbankan di Bursa

Efek Indonesia. Proceeding

PESAT

Universitas

Gunadarma. Vol. 4 Oktober 2011:160-164.

Anoraga, Pandji dan Piji Pakarti.

2008. Pengantar Pasar Modal.

Edisi Revisi. Jakarta: PT

Rineka Cipta.

Asnita. 2013. Pengaruh Kinerja

Keuangan terhadap Harga

Saham pada Industri Farmasi

di BEI Periode 2008-2010.

Jurnal Dinamika Manajemen.

Vol. 1 No. 2 April - Juni 2013:

106-119.

Bank Indonesia. 2014. Laporan

Perekonomian Indonesia 2014.

Jakarta.

Brigham and Houston. 2001. Manajemen Keuangan Edisi

Kedelapan Buku 1. Jakarta: Erlangga.

Darmadji, Tjiptono dan Hendry $\mathrm{M}$.

Fakhruddin. 2008. Pasar Modal di Indonesia:
Pendekatan Tanya Jawab. Edisi

Kedua. Jakarta: Salemba

Empat.

. 2012. Pasar Modal di Indonesia: Pendekatan Tanya jawab. Edisi Ketiga. Jakarta : Salemba Empat.

Dewi, Putu Dina Aristya dan I.G.N.A. Suaryana. 2013. Pengaruh EPS, DER, dan PBV terhadap harga saham. E-Jurnal Akuntansi Universitas Udayana 4.1 (2013): 215-229.

Efni, Yulia. 2008. Pengaruh Suku Bunga Deposito, SBI, Kurs, dan Inflasi Terhadap Harga Saham Perusahaan Real Estate dan Property Di BEI. Jurnal Manajemen Fakultas Ekonomi Universitas Riau: 1-11.

Ghozali, Imam. 2009. Aplikasi Analisis Multivariate dengan Program SPSS, Cetakan ke IV. Semarang: Badan Penerbit UNDIP.

Godfrey, J., A. Hodgson, S. Holmes, dan A. Tarca. 2006. 
Accounting Theory. 6th

Edition. Australia: John Wiley \& Sons Australia Ltd.

Harahap, Sofyan S. 2008. Analisa Kritis atas Laporan Keuangan. Jakarta: PT. Raja Grafindo Persada.

Hartono, J. 2008. Teori Portofolio dan Analisis Investasi. Edisi 5. Yogyakarta: BPFE.

Kasmir. 2012. Analisis Laporan Keuangan. Jakarta: PT Rajagrafindo Persada.

Krisna, Anak Agung Gde Aditya dan Ni Gusti Putu Wirawati. 2013. Pengaruh Inflasi, Nilai Tukar Rupiah, Suku Bunga SBI pada Indeks Harga Saham Gabungan di BEI. E-Jurnal Akuntansi Universitas Udayana 3.2 (2013): 421-435.

Mishkin, Frederic S. 2001. The Economic Of Money, Banking and Financial Market. New York: Addison Wesley.
Munawir. 2011. Analisis Laporan Keuangan. Edisi Kelima. Yogyakarta: Liberty.

Otoritas Jasa Keuangan. 2014. Statistik Pasar Modal.

Patar, Andrew., Darminto dan Muhammad Saifi. 2014. Faktor internal dan Eksternal yang mempengaruhi pergerakan harga saham. (Studi Pada Saham-Saham Indeks LQ45 Periode 2009 - 2013). Jurnal Administrasi Bisnis (JAB). Vol. 11 No. 1 Juni 2014:1-8.

Pratama, Aditya dan Teguh Erawati. 2014. Pengaruh Current Ratio, Debt Equity Ratio, Return on Equity, Net Profit Margin dan Earnings Per Share terhadap Harga Saham. Jurnal Akuntansi Vol. 2 No. 1 Juni 2014:1-8.

Putong, Iskandar. 2002. Ekonomi Mikro dan Makro. Edisi Kedua. Jakarta : Ghalia Indonesia. 
Rusli, Linda., Tan Kwang En dan Meythi. 2011. Pengaruh Likuiditas dan Profitabilitas Terhadap Harga Saham Perusahaan Manufaktur yang Terdaftar di Bursa Efek Indonesia. Jurnal Bisnis Manajemen dan Ekonomi. Volume 10, No. 2, Mei 2011: 2671-2684.

Sawir, Agnes. 2005. Analisis Kinerja Keuangan dan Perencanaan Keuangan Perusahaan. Jakarta: Gramedia Pustaka Utama.

Simorangkir, Iskandar dan Suseno. 2004. Sistem dan Kebijakan Nilai Tukar. Jakarta: Pusat Pendidikan dan Studi Kebanksentralan (PPSK) Bank Indonesia.

Sudana, I Made. 2011. Manajemen Keuangan Perusahaan Teori dan Praktik. Jakarta: Erlangga.

Sukirno, $\quad$ Sadono. 2013. Makroekonomi Teori Pengantar. Edisi Ketiga. Jakarta: PT RajaGrafindo Persada.
Suliyanto. 2011. Ekonometrika Terapan: Teori dan Aplikasi dengan SPSS. Yogyakarta: Penerbit Andi.

Suparmono. 2004. Pengantar Pengetahuan Pasar Modal. Yogyakarta: UPP AMP YKPN.

Tandelilin, Eduardus. 2001. Analisis Investasi dan Manajemen Portofolio. Edisi Pertama. Yogyakarta : BPFE. 2010. Portofolio dan Investasi: Teori dan Aplikasi. Edisi Pertama. Yogyakarta: Kanisius.

Tuerah, M. Haikal. 2015. "Analisis Pengaruh ROA, EPS, NPM, Inflasi, dan Kurs Terhadap Harga Saham pada Perusahaan Sektor Makanan dan Minuman yang Terdaftar di Bursa Efek Indonesia”, Skripsi, Fakultas Ekonomi dan Bisnis UNSOED Purwokerto.

Wicaksono, Hendra A. 2013. Pengaruh Current Ratio, Debt 
to asset ratio, Total asset turnover, Return on equity, Suku bunga, Kurs valuta asing, Inflasi, dan Kas Dividen terhadap Harga Saham. Jurnal Profita 2013:50-67.

Wolk, Harry I., Michael G. Tearney, dan James L Dodd. 2000. Accounting Theory: A Conceptual and Institutional Approach. South-Western College Publishing.
Website:

http://www.idx.co.id diakses tanggal 4 April 2015. http://www.kemenperin.go.id/a rtikel/9400/2015,-Sektor-Manu faktur-Dibidik-Tumbuh-7,5, diakses tanggal 4 April 2015.

http://www.artikelsiana.com/2015/01/penge rtian-inflasi-jenis-penyebab-dampa k.html diakses tanggal 3 September 2015. 